\title{
Modeling SOFC \& GT Integrated-Cycle Power System with Energy Consumption Minimizing Target to Improve Comprehensive cycle Performance (Applied in pulp and paper, case studied)
}

\author{
H.A. Ozgoli ${ }^{1, *}$, H. Ghadamian ${ }^{2}$, N. Andriazian ${ }^{3}$ \\ ${ }^{1,2,3}$ Department of energy, science \& research campus, Islamic Azad University, Tehran, IRAN \\ *Corresponding author. Tel: +98 9122449408, Fax: +98 21 44232205, E-mail: a.ozgoli@srbiau.ac.ir
}

\begin{abstract}
This study has considered hybrid system SOFC/GT with the new approach. This cycle, as a power plant is designed to reduce losses and improve comprehensive cycle performance. In the first part cycle, fluidized bed system with biomass (wood chips) fuel using gas cleaning mechanism, produce combustible gases which are required fuel combustion chambers of steam reformer and the GT. Second part cycle, required hydrogen for SOFC system is supplied through external SR. In the third part, the treated bio syn-gas from the cleaning unit outlet, in conjunction with recycled exhaust gases of the cell's anode will feed SR and GT combustors. In the fourth part cycle, flue gas would pass through heat recovery steam generator. Thus, high pressure and low pressure steams with values $3.39 \& 0.45 \mathrm{ton} / \mathrm{hr}$, respectively are generated. In this study, SOFC and GT with a capacity of $1000 \& 750.81 \mathrm{~kW}$ respectively are designed. Overall efficiency of power production $74.4 \%$ is obtained. In comparison with similar study done in 2008 at the University of Delft, that overall $47 \%$ efficiency, increasing the efficiency of such systems has been viewed.
\end{abstract}

Keywords: Solid Oxide Fuel Cell (SOFC), Gas Turbine (GT), Bio syn-gas, Fluidized Bed (FB), Steam Reformer (SR), Comprehensive Cycle Performance

\section{Introduction}

Recent studies have indicated that in integrated SOFC/GT cycles which employ natural gas, the overall efficiency of the system is estimated to be $50 \%$ to $60 \%$. Burning and gasifying the biomass and combining the result with SOFC/GT system, enables the hybrid system to contribute to an efficient power plant [1], [2]. Generally, in order to generate power in a cost effective way and develop generating systems, distributed power generation has recommended an effective measure [3], [4]. The general prospect of the present study has been the integration of industries which normally generate combustible wastes and plants that consume such wastes. This study mainly focuses on de signing an integerated SOFC/GT power plant based on burning biomass in combustion chambers and reforming the natural gas in a steam reformer. The a-grade wood has been considered as the biomass in the planning and $1.75 \mathrm{MW}$ of the electrical energy is expected to be generated. According to the field available technologies and the studies which have already been conducted in this field, our proposed cycle can be considered as a new approach in designing similar power plants in the future. A thorough analysis of energy in the system will determine and visualize the losses and realize the thermodynamically efficiency.

\section{System Approach}

\subsection{Improving the efficiency}

1- Trying to improve energy generation efficiency and enhancing energy transfer and distribution efficiency (utilizing CHP systems and cogeneration to maximize absorption and recovery).

2- Determining the essential fuel and each of the aforementioned units' efficiency. 


\subsection{Employing renewable form of energy}

1- Calculation related to considerable amount of electrical energy by using renewable forms of energy (SOFC/GT).

2- Estimating a portion of required fuel by renewable forms of energy (Biomass gasification system).

\subsection{Managing the industrial process products}

1- Putting to use the by-products of industrial process (such as pulp and paper industry) to supply the fuel required for SR and GT systems [9].

2- Making use of hot flue gases and generated heat, for consuming in the comprehensive cycle and auxiliary units.

\section{System Configuration}

As it is illustrated in the figure 1, this system is comprised of different sections which have been pinpointed by the sections' names. These sections are as the following:

Fluidized bed system and gas cleaning, External Reforming SOFC system, GT system, $\mathrm{HRSG}^{1}$ system, heat exchangers for pre heating fuel and air generating steam required for the reformer. Burning and gasification of the fuel biomass (wood) is usually preformed in the FB system. The gasifier operates at $500^{\circ}$ and 4 bar. Heat is transferred by circulating the materials. Impurities within the components of the bed are separated from the gases by a $\mathrm{C}$, $\mathrm{SiO}_{2}$ separator [6], [7]. The gas which is exhausted from FB unit cannot be directly used within SR combustion chamber and GT. This is mainly due to the fact that the gas turbine. Therefore components such as $\mathrm{H}_{2} \mathrm{~S}, \mathrm{SO}_{2}, \mathrm{COS}$ and $\mathrm{NH}_{3}$ are effectively removed from the exhaust gas [8]. Form chemical prospect, performing gas treatment, within the higher temperature ranges, seem to be able to be really demanding and imposes restriction treatment process. It is generally believed that the hot gas needs to be appropriately cooled down before being treated. Hot gas temperature is diminished to $500^{\circ} \mathrm{C}$ in the heat exchanger [9], [10]. The cooled exhaust gas from cooling and treatment units is then mixed with hot exhaust gas from SOFC which mainly contain non-reacted steam and hydrogen. The mixture will then be transferred to GT and SR combustion chambers. The SR units have been employed to supply the fuel required for SOFC. This unit makes use of natural gas reformation to produce the fuel. The operating temperature and pressure of SR are considered to be $800^{\circ \mathrm{C}}$ and $1 \mathrm{bar}$ respectively [11]. The treated syn-gas from the cleaning unit outlet, in conjunction with recycled flue/exhaust gases of the cell's anode (off-gas), which contains some combustible remnants; will feed SR and GT combustors. The pressurized air is directed towards the cathode. Fuel cell with an external reformer (SOFC) is able to directly turn hydrogen, which is the product of already reformed natural gas method, in to electricity. The hot exhaust gas from the cathode (off-gas) is recycled to supply the gas turbine. The expanded flue gas has been used to recuperate the incoming air, after it had been pressurized. An air compressor attached to the turbine supplies the essential air for the integrated SOFC/GT system. Connecting the turbine to the generator, the second electrical current in the cycle is generated. HRSG system has been designed based on a dual pressure-mode in which both high and low steam pressures are generated, in order to improve the system performance and enhance steam generation rate. The results of the previous studies took the HRSG planning process into consideration. There is a feed water boiler in the methodology where the water supply after leaving LP (Low Pressure) economizer is split into two parts. One portion is directed

\footnotetext{
2- Heat Recovery Steam Generator
} 
towards LP evaporator and another one to HP (High Pressure) economizer. Figure 2 illustrates the schematic performance mechanism of HRSG in the cycle [12].

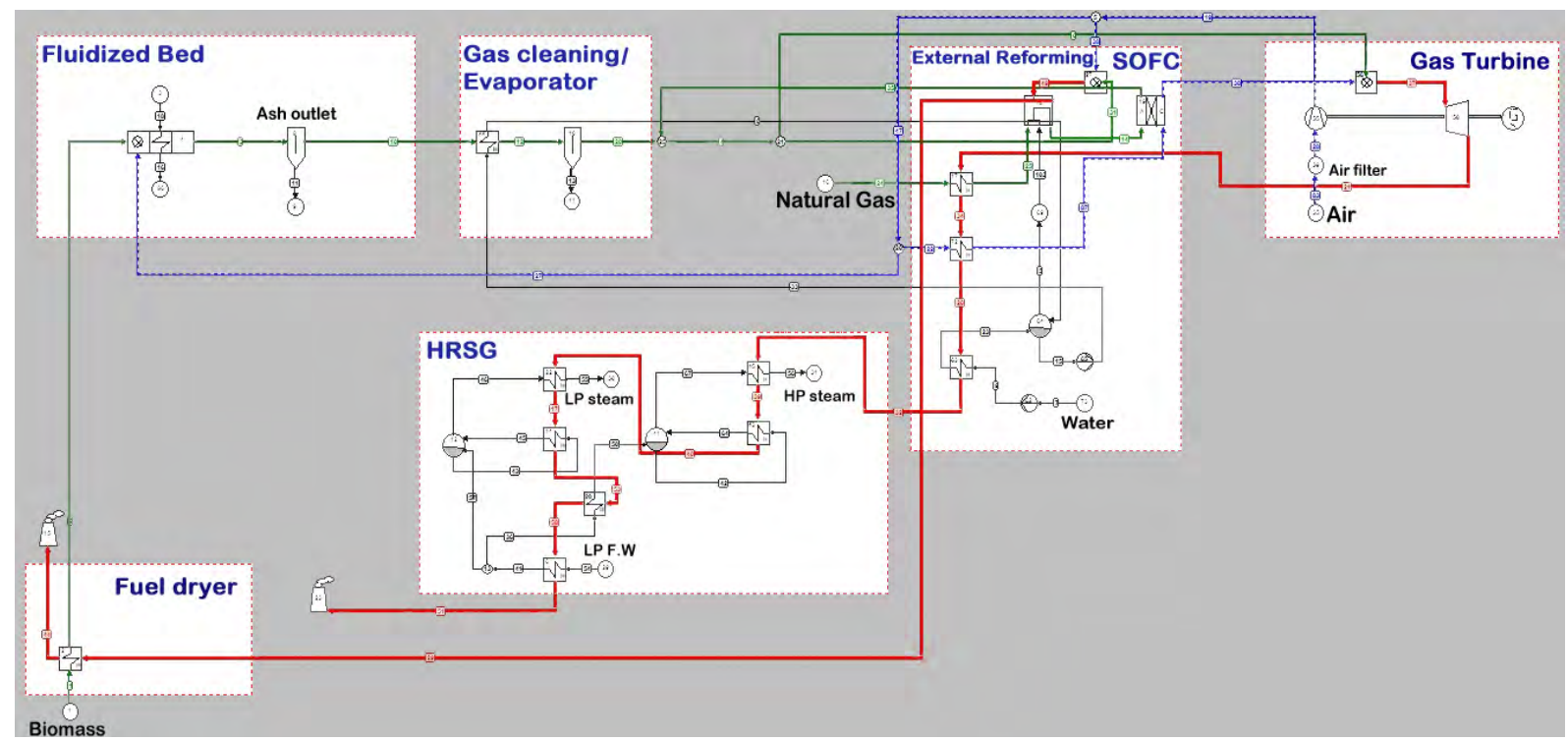

Fig. 1. Schematic of hybrid system

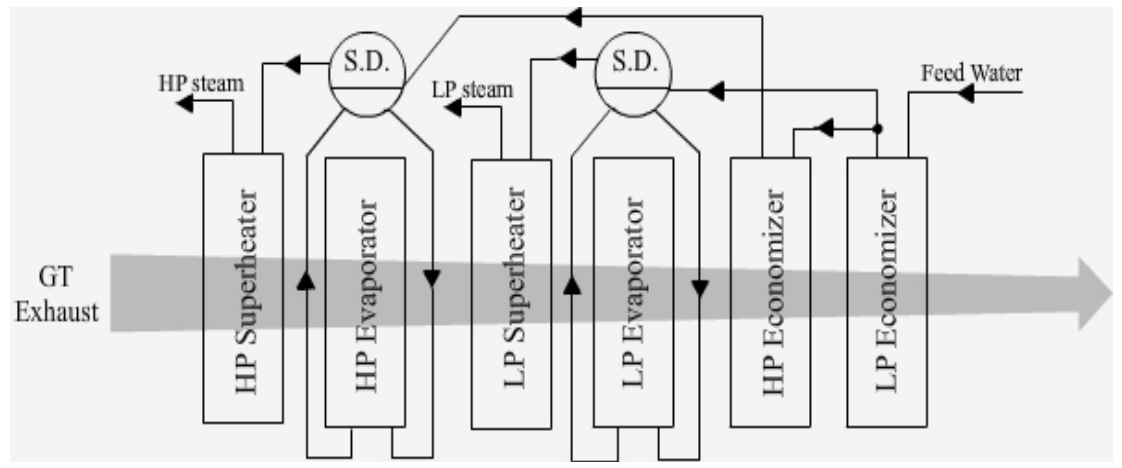

Fig. 2. Schematic of HRSG mechanism

\section{System modeling}

\subsection{Model assumptions}

In order to evaluate the system and obtain a balance between mass and energy of the cycle, Cycle-tempo software was employed. The main purpose of using such software was to create a model in the study state. Therefore a model consisting of subsystems has been created. Achieving a consensus on subsystem calculations is the prime objective in creating this model. There are some general assumptions which have been made in creating this model [13], [14].

- The whole system operates at steady state.

- In SR steam generating section, isentropic efficiency of the pump after the steam drum equals $75 \%$ and prior to the economizer is $85 \%$.

- Isotopic efficiency of the compressor and gas turbine are $87 \%$ and $86 \%$ respectively.

- The mechanical efficiency for compressor and gas turbine is set to $99 \%$.

- The generator efficiency is set to $98 \%$.

- The pressure drop within the heat exchanger has been assumed to be zero. Pressure and temperature prior to the system have been listed in table 1. 
Table 1. Pressure and temperature of fuels, air and water inlet to the system

\begin{tabular}{ccc}
\hline Sink name & Pressure(bar) & Temperature $\left({ }^{\mathrm{CC}}\right)$ \\
\hline Biomass & 4 & 15 \\
Natural gas & 1.18 & 15 \\
Air & 1.013 & 15 \\
Water* & 1.2 & 20 \\
\hline
\end{tabular}

* Inlet water in SR system

The operational temperature of the fuel cell is $950^{\circ \mathrm{C}}$ and the pressure is $3.45 \mathrm{bar}$. The fuel cell area is supposed to be $700 \mathrm{~m}^{2}$ and the fuel cell resistance $0.75 \Omega . \mathrm{cm}^{2}$. The efficiency of the $\mathrm{DC} / \mathrm{AC}$ converter is $96 \%$.

Figure 1 illustrates the SOFC and GT integrated cycle power system schematically. Based on temperature and pressure, two different types of system are generated in HRSG unit. High pressure steam (50 bar) which is as hot as $470^{\circ} \mathrm{C}$ and low presser steam of 15 bar and $270^{\circ} \mathrm{C}$.

\subsection{Preliminary discussion}

With a view to reach a higher efficiency in SOFC/GT hybrid system, the following points should be considered in planning the cycle.

- The combustible gases which have been produced in FB can be directly used in SR and GT combustors.

- Making use of the released heat while cooling the gas leaving FB and prior to cleaning which can be used to supply the necessary steam for SR unit.

- Employing a portion of the gas turbine flue gas heat in pre heating the fuel (natural gas) and the air entering the SOFC system.

- Using the pressurized air by the gas turbine compressor in the cathode.

- Using a great deal of gas turbine flue gas heat to generate steam in HRSG.

- Making use of the exhaust heat from SR in drying biomass entering the system.

After considering the application of a SOFC system with a constant power of $1 \mathrm{MW}$ for reaching such power in GT, the present study adjusted reaction pressure and outlet pressure of the FB unit to 4 bar. The outlet pressure of the compressor was sent to 3.46. Minimizing fuel consumption was one of our other objectives.

Comparing this hybrid system with $1.75 \mathrm{MW}$ gas turbine system within similar temperature \& pressure states, implies a considerable reduction in fuel consumption. Table 2 shows the comparison of these two systems.

Table 2. Comparison of fuel consumption in hybrid and GT systems with similar capacity

\begin{tabular}{ccc}
\hline System type & $\begin{array}{c}\text { Natural gas consumption } \\
(\mathrm{kg} / \mathrm{hr})\end{array}$ & $\begin{array}{c}\text { Biomass consumption } \\
(\mathrm{kg} / \mathrm{hr})\end{array}$ \\
\hline Hybrid system & 159.41 & 129.6 \\
Gas Turbine system & 1396.8 & - \\
\hline
\end{tabular}

In order to substitute the integrated system of heat and power generation, a pulp manufacturing plant which is also capable to be developed to produce pulp and paper (the 22Bahman particle board manufacturing company located in northern city of Behshahr in Iran) was considered. This plant is traditionally supplied by the regional electrical transmission network in tandem with burning fossil fuel, to run its manufacturing process. The main characteristics of this study are presented in table 3 . The annual production of the 
plant has been estimated to be $41438880 \mathrm{~kg}$. The capacity which has been selected for the hybrid system is in congruity with electrical power consumption of the plant.

Table 3. Energy consumption comparison between the Traditional and integrated power generation

\begin{tabular}{llc}
\hline \multirow{2}{*}{ Traditional system } & \multicolumn{1}{c}{ Description } & Energy unit \\
\cline { 2 - 3 } & Electric power consumption & $52753716 \mathrm{MJ}$ \\
& Heat consumption & $60802100 \mathrm{MJ}$ \\
& Specific energy consumption (SEC) & $5.28 \mathrm{MJ} / \mathrm{kg}$ \\
\cline { 2 - 3 } Hybrid system & Electric power generation capacity & $1.75 \mathrm{MW}$ \\
& Heat consumption & $97136501 \mathrm{MJ}$ \\
& Specific energy consumption (SEC) & $2.34 \mathrm{MJ} / \mathrm{kg}$ \\
\hline
\end{tabular}

Based on the results from the study, the specific energy consumption shows a decrease of $2.94 \mathrm{MJ} / \mathrm{kg}$. The first reason for such decrease is electrical power generation in the new system. The second reason to be mentioned is daily generation of $690.65 \mathrm{~kg}$ waste product which constitutes the $22 \%$ biomass fuel essential for hybrid system.

\section{Results and conclusion}

\subsection{Quantitative approach}

In the present model, according to the power generation capacity of the integrated SOFC/GT system which is $1.75 \mathrm{MW}$ the mass flow rate entering biomass is set to be $129.6 \mathrm{~kg} / \mathrm{hr}$. The already generated gas leaved FB with 4 bar and $1543.04^{\circ} \mathrm{C}$. The main ingredients and their mole fractions have been shown in table 4 .

Table 4. Mole fractions of FB exhaust gases

\begin{tabular}{cc}
\hline Component & Mole fraction (\%) \\
\hline $\mathrm{H}_{2}$ & 7.07 \\
$\mathrm{~N}_{2}$ & 49.72 \\
$\mathrm{CH}_{4}$ & 4.34 \\
$\mathrm{H}_{2} \mathrm{O}$ & 18.45 \\
$\mathrm{CO}_{2}$ & 18.42 \\
$\mathrm{CO}$ & 1.37 \\
$\mathrm{AR}$ & 0.59 \\
\hline
\end{tabular}

Here, $31.9 \mathrm{~kg} / \mathrm{hr}$ ash leaves the system as mentioned earlier; the mixture contains some harmful gases which will affect the SR and GT system unless they are controlled. The gas which has undergone cleaning process is mixed with the gas leaving the fuel cell anode under a pressure around 3.45 bar. The hot flue gases $\left(1200^{\circ} \mathrm{C}\right.$ ) from the combustor enter SR. SR requires steam with a flow rate of $460.26 \mathrm{~kg} / \mathrm{hr}$. In view of the reactions occurred in SR, the convenient fuel with a mass flow rate of $619.67 \mathrm{~kg} / \mathrm{hr}$, are generated in SOFC. The fuel cell operating at $950^{\circ \mathrm{C}}$ produces $1000 \mathrm{~kW}$ of electrical energy. Not all fuel is converted in the SOFC stack; the fuel utilization is $85 \%$. The SOFC characteristics for current \& power densities are rendered $1963.04 \mathrm{~A} / \mathrm{m}^{2} \& 1488.1 \mathrm{~W} / \mathrm{m}^{2}$ respectively. The $\mathrm{TIT}^{1}$ is $1100^{\circ} \mathrm{C}$. Expansion of the mixture of gases entering the turbine $1276 \mathrm{~kJ} / \mathrm{kg}$ generates power. Having

1- Turbine Inlet Temperature 
preheated the fuel and air in the SOFC system, and also exchanged heat in SR steam generating economizer, the flue gas from the gas turbine enters HRSG; meanwhile its energy content and temperature are $3908.7 \mathrm{~kW}$ and $782.94^{\circ} \mathrm{C}$ respectively. Economizer outlet is split into two $183^{\circ} \mathrm{C}$ currents, which enter the LP and HP evaporators. The outlet pressures of HP and LP evaporators reach 15 bar and 50 bar respectively. The flow rate of steam leaving HP and LP super heater outlets are $0.45 \mathrm{ton} / \mathrm{hr}$ and $3.39 \mathrm{ton} / \mathrm{hr}$ respectively. Energetic HRSG efficiency equal to $92 \%$ was obtained. In table 5 the energy inputs and consumptions of the system for the conversion of biomass into electricity are presented.

Table 5. Energy input and consumption of the biomass gasifier and SOFC-GT hybrid system

\begin{tabular}{ccccc}
\hline & Biomass & Natural Gas & Fuel Cell & Gas Turbine \\
\hline Absorbed & 670.32 & 1682.81 & - & - \\
power(kW) & & & 1000 & 750.81 \\
$\begin{array}{c}\text { Delivered gross } \\
\text { power(kW) }\end{array}$ & - & - & \\
\hline
\end{tabular}

\subsection{Qualitative approach and recommendations}

In the Figure 3, the nature of heat recovery and constant output is reasonable. Increase in bio fuel consumption is mainly due to FB system performance as a bottleneck. We have to cross out (as a decrease) in some of the objective to increase Bio. In reality if there is a necessity for increasing the bio fuel, right after that increase ash production rate is maximized to a great extent and puts a restriction on power generation and heat recovery.
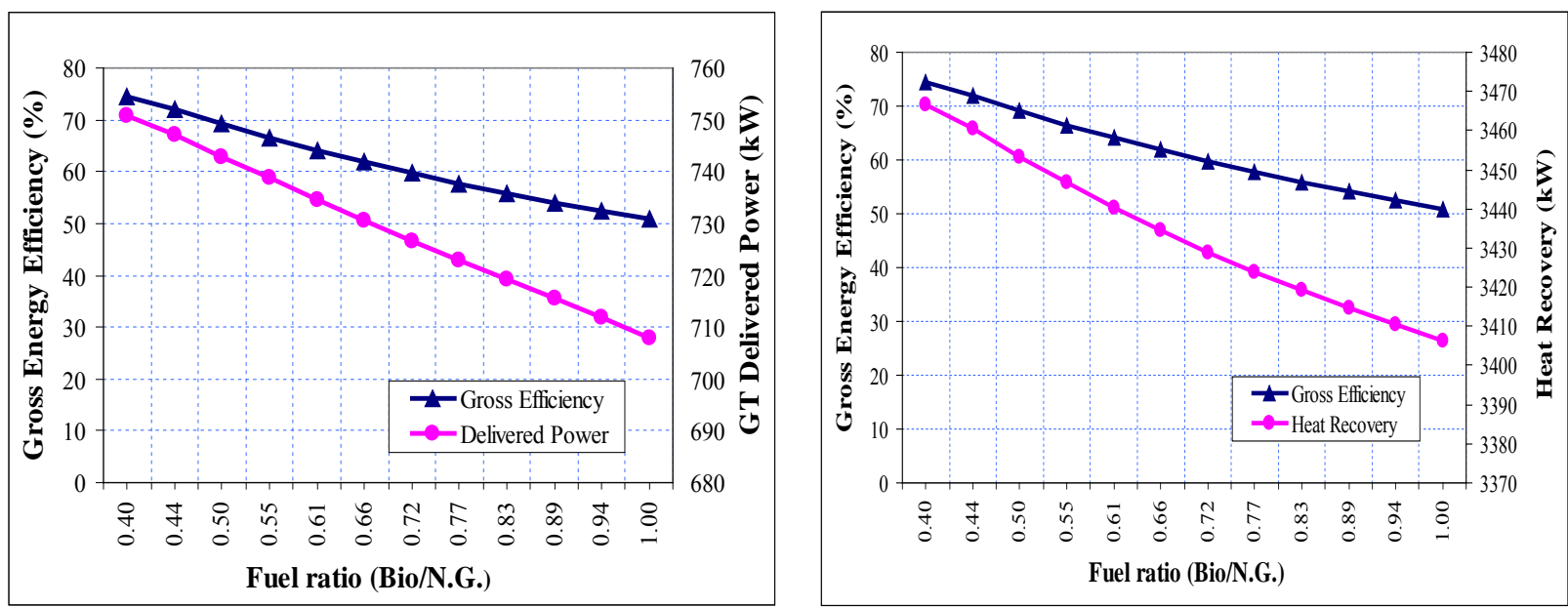

Fig. 3. Fuel ratio variations against hybrid system energy profiles

The point that is worth mentioning is that geometry of the bed and incoming fuel level can be increased but the thermal value and residence time, which is considered to be a more important factor, are limited. In Figure 4(a), the real difference in curves' tails is strongly depends on irreversibilities that taking place by more rated pressure in GT. (As GT's property, sacrificing efficiency against more power production is technically predicted). 


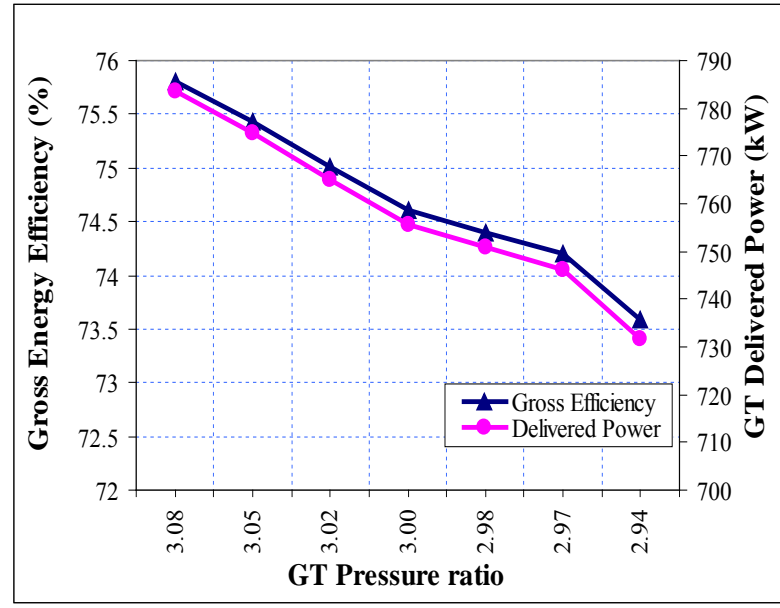

(a)

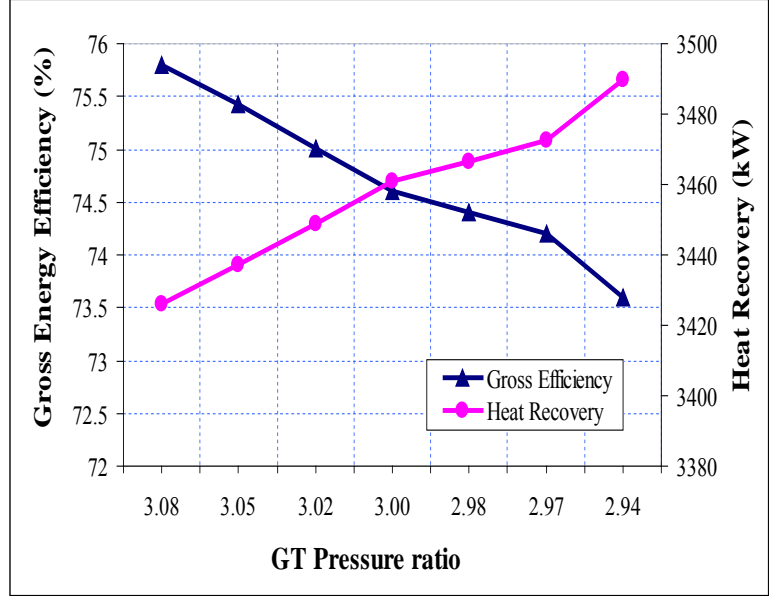

(b)

Fig. 4. GT pressure ratio variations against hybrid system energy profiles

But in Figure 4(b), the pressure ratio in GT is working as a balancing element, which is correlated directly with GT delivered power and inversed with Heat recovery. These explanations are clearly demonstrated in mentioned graphs. In this stage a trade-off point is found at 3 for pressure ratio, which covers all two targets named GT delivered power and heat recovery. This point can be applied as a nominative reference for our designed system called best practice point in our modeling approach. In the comparison of graphs Nos. 4(a), 4(b) it can be observed that mentioned increased irreversibilities based on pr essure decreasing, would be transferred to stack as an increased source for heat recovery. The best proportion for electricity generation in an integrated SOFC/GT system is 60 to 40 [15]. Therefore the power which is expected to be generated by the system is planned in such a way that $1000 \mathrm{~kW}$ is generated by SOFC. Likewise according to the assumptions and calculations conducted, the power generated by GT equals $750.81 \mathrm{~kW}$. As it c an be implied from table 5, the gross efficiency of the cycle is $74.4 \%$. This can be compared with the gross efficiency of the similar study which had been conducted in university of Delft [3]. It is thus evident that an increase in gross efficiency has been fulfilled. Such increase can be attributed to the following reasons.

1. Direct burning of FB combustible gases output at GT combustion chambers and SR

2. Using natural gas (with a higher percentage of hydrogen) as fuel input SR system and its sense of more appropriate quality in fuel Sign for SOFC

3. Changes in the recovery position of SOFC gas combustible system, comes from SOFC process recycling by adding them to the purified gas cleaning unit (obviously, internal reforming itself is a part of the energy consumption indeed)

In order to obtain a higher efficiency and higher steam mass flow rate generated by the system, some changes in heat exchangers' locations were applied. The pinch point which is located between the evaporator's outlet and inlet has been adjusted to be $10^{\circ} \mathrm{C}$. LP and HP steam produced in the cycle can be used for steam units placed side-consumer. Also adding a steam cycle power generation, steam production can be used to generate electricity. Thus, the overall efficiency of power production systems will increase.

\section{References}

[1] L. E. Fryda, K. D. Panopoulos, and E. Kakaras, Integrated Combined Heat and Power with Biomass Gasification and SOFC-micro Gas Turbine, VGB PowerTech 4, 2008, pp.66-72.

[2] F. Calise, M. Dentice d' Accadia , et al., Single-level optimization of a hybrid SOFC-GT power plant, Journal of Power Sources 159 ,2006, pp.1169-1185 
[3] R. Toonssen, N. Woudstra, and A.H.M. Verkooijen, Reference System for a Power Plant Based on Biomass Gasification and SOFC, Delft University of Technology Energy Technology, Process \& Energy department, 2008

[4] F. Calise, M. Dentice d' Accadia, et al., Full load synthesis/design optimization of a hybrid SOFC-GT power plant, Energy 32, 2007, pp.446-458

[5] M. Sucipta, S. Kimijima, and K. Suzuki, Biomass solid oxide fuel cell-micro gas turbine hybrid system: Effect of fuel composition, Journal of Fuel Cell Science and Technology 155, 2008, pp.B258-B263

[6] S. Baron, N. Brandon, et al., The impact of wood-derived gasification gases on Ni-CGO anodes in intermediate temperature solid oxide fuel cells, Journal of Power Sources 126, 2004, pp. 58-66.

[7] K.V. Van der Nat, N. Woudstra, Evaluation of several biomass gasification processes for the production of a hydrogen rich synthesis gas, Proceedings International Hydrogen Energy Congress and Exhibition IHEC 2005

[8] W. Doherty, A. Reynolds, D. Kennedy. Modeling and Simulation of a Biomass Gasification-Solid Oxide Fuel Cell Combined Heat and Power Plant Using Aspen Plus, Proc. 22nd International Conference on Efficiency, Cost, Optimization, Simulation and Environmental Impact of Energy Systems, 2009

[9] R. Toonssen, P. V. Aravind, et al., System Study on H ydrothermal Gasification Combined With a Hybrid Solid Oxide Fuel Cell Gas Turbine, Fuel Cells, 10, 2010, pp. 643-653

[10]S. Poulou, E. Kakaras, High tempera-ture solid oxide fuel cell integrated with no-vel allothermal biomass gasification: Part II: Exergy analysis, Journal of Power Sources 159, 2006, pp. 586-594

[11]A. Sordi, E. P. da Silva, et al., Thermodynamic Simulation of Biomass Gas Steam Reforming for a Solid Oxide Fuel Cell (SOFC) System, Brazilian Journal of Chemical Engineering 26, 2009, pp. 745-755

[12]N. Andriazian, off-design performance modeling of gas turbine cycles considering exergy-cost trade-off and CO2 capture, M.Sc thesis, IAU, 2008

[13]EG\&G Technical Services Inc., Fuel Cell Handbook, U.S. Dept. of Energy Office of Fossil Energy National Energy Technology Laboratory, Morgantown, West Virginia, 2004

[14]L. Fryda, K.D. Panopoulos, and E. Kakaras, Integrated CHP with autothermal biomass gasification and SOFC- MGT, Energy Conversion and Management 49, 2008, pp. 281 290

[15]T.W. Song , J.L. Sohn, et al., Performance characteristics of a MW-class SOFC/GT hybrid system based on a commercially available gas turbine, Journal of Power Sources 158, 2006, pp.361-367 